\title{
Impact of lime treated soils performance on design of earthfill dikes
}

\author{
Nicolas Nerincx ${ }^{1}$, Stéphane Bonelli ${ }^{2}$, Daniel Puiatti ${ }^{3}$, Gontran Herrier ${ }^{4}$, Jean.-Jacques Fry ${ }^{5}$, Rémy Tourment ${ }^{2}$ and Sylvie \\ Nicaise ${ }^{2}$ \\ ${ }^{1}$ ISL Ingénierie, Lille (France) \\ ${ }^{2}$ Irstea, Aix-en-Provence (France) \\ ${ }^{3}$ DPST Consulting, Villemomble (France) \\ ${ }^{4}$ Lhoist Recherche et Développement, Nivelles (Belgique) \\ ${ }^{5} \mathrm{EDF}-\mathrm{ClH}$, Le Bourget du Lac (France)
}

\begin{abstract}
Nowadays soil treatment with lime in civil engineering is widespread in many countries on all continents, within several construction fields. The interest of the hydraulic works community regarding this technique is currently growing. It has been indeed shown during the last decade that appropriate treatment technologies provide lime treated soils with high level properties such as excellent homogeneity, low permeability, internal and external erosion resistance and mechanical stability. Those have been shown in laboratory and for some properties with full scale experiments. The so conferred soil properties can lead to innovative earthfill dams and dikes designs by addressing some of the typical designer's problems, such as stability, watertightness, internal erosion, surface protection and flood control. However, lime treated soil external erosion resistance is still to be quantified in the field for proper designing and dimensioning of lime treated soil external erosion protection or spillways. With this purpose, an experimental earthfill dike has been built along the river Vidourle (France) in July 2015, in the frame of the French R\&D program "DigueELITE". This $50 \mathrm{~m}$ long and 3,5 $\mathrm{m}$ high dike is made of lime treated silt and is provided with sensors (succion, water content and temperature) and piezometer in order to be monitored. It will also be tested against surface erosion. The final objective of this $R \& D$ program is to provide guidelines for designing innovative overflow resistant earthfill dikes. This article describes the performance reached by lime treated soils and associated design requirements and application; the experimental dike construction and lessons learned; the monitoring program; the dike design perspectives opened by soil treatment.
\end{abstract}

\section{General}

Lime treatment of soils has grown considerably since the mid-1940's for the stabilisation of clayey gravel and sand used in the construction of pavement bases of roads, highways, airfields, railroad, etc. (Little 1995). In Europe, since more than 60 years, the technique has also been developed to improve and stabilise silty and clayey soils in earthworks for the same field of applications.

The development in the field of hydraulic structures has been slower. The main benefits of this technique are reported by Gutschick (1978) : preventing softening while underwater, preventing leakage and resisting to erosion from flowing water. The reduction of shrinkage and swelling movements of high plasticity index soils (heavy clays) after lime treatment, is also an important benefit for the reduction of the occurrence and development of cracks. Several cases of construction, restoration or reinforcement of hydraulic structures were realised by American and Australian authorities since the 1970 's $[1 ; 2,3,4,5,6,7,8,9]$. In addition to the very good mechanical and hydraulic performance of lime treated soils, the technique is reported to decrease the overall construction costs, offering the possibility to reuse local soils with poor initial engineering properties, to improve the workability of materials, to take advantage of potential design changes.

In Europe, lime treatment of soils for hydraulic earthen structures was used in the late XIXth century. It reappeared 30 years ago (levees and small dams in Czech Republic and France for example), thanks to the initiatives of geotechnical engineers who, aware of the uses in road applications, had the opportunity to transpose them to hydraulic structures.

Important works in laboratory and full-scale, were used to quantify the performance of lime treated soils in hydraulic structures such as stability, watertightness, internal erosion $[10,11,12]$. These results are taken into account by the CMD Committee (P) of ICOLD in the ongoing drafting of a bulletin dedicated to Cemented Soil Dams (CSD).

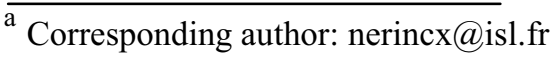


However, the resistance to external erosion is still to be quantified in the field for the proper design of protection against surface erosion. For this purpose, an experimental earthfill dike made of lime treated silt has been built in July 2015 along the river Vidourle (France) in Aimargues, in the frame of the French R\&D program "DigueELITE".

\section{Performance and design requirements}

Calcium air lime is a reactant obtained by calcination of pure limestone. It can be in the form of either calcium oxide $(\mathrm{CaO})$ also called quicklime, or in the form of calcium hydroxide $(\mathrm{Ca}(\mathrm{OH}) 2)$ also called hydrated lime. When mixed with a clay containing soil, lime reacts differently than a cement. On short term : reduction of the moisture content, particularly when using quicklime, flocculation of the clay minerals, modification of the geotechnical characteristics (Atterberg limits and Proctor curve) and increase of the bearing capacity (immediate CBR). On long term : slow combination with the clay minerals of the soil ("pozzolanic" reaction) and increase of the mechanical performance (CBR after immersion, Unconfined Compressive Strength and cohesion) [13].

\subsection{Mechanical performance}

The kinetics of the long term reaction and the performance of a lime treated soil depend on the activity and the proportion of the clay. Examples of mechanical performance are given in tables 1 and 2 .

\begin{tabular}{|c|c|c|c|}
\hline Soil & PI & Quicklime & Rc 7 days \\
\hline Silt & 7 & $4 \%$ & 0,67 \\
\hline Silty clay & 25 & $5 \%$ & 0,60 \\
\hline
\end{tabular}

\begin{tabular}{|c|c|c|c|}
\hline Soil & $\mathbf{R c} 28 \mathbf{d}$ & $\mathbf{R c} 90 \mathbf{d}$ & $\mathbf{R c} 365 \mathbf{~ d}$ \\
\hline Silt & 0,95 & 1,86 & 4,50 \\
\hline Silty clay & 0,95 & 3,79 & 5,19 \\
\hline
\end{tabular}

Table 1. Unconfined Compressive Strength (in $\mathrm{MPa}$ ) with time of two lime treated soils

\begin{tabular}{|c|c|}
\hline & $\begin{array}{c}\text { Non } \\
\text { treated }\end{array}$ \\
\hline Time (days) & 0 \\
\hline$\varphi^{\prime}($ deg.) & 37 \\
\hline$c^{\prime}(\mathrm{kPa})$ & 5 \\
\hline
\end{tabular}

\begin{tabular}{|c|c|c|c|c|c|}
\hline & \multicolumn{5}{|c|}{ Treated with 3 \% quicklime } \\
\hline $\begin{array}{c}\text { Time } \\
\text { (days) }\end{array}$ & 0 & 7 & 90 & 300 & 680 \\
\hline$\varphi^{\prime}($ deg.) & 37 & 37 & 36 & 37 & 37 \\
\hline$c^{\prime}(\mathrm{kPa})$ & 19 & 19 & 38 & 103 & 138 \\
\hline
\end{tabular}

Table 2. Cohesion and friction angle with time of a silty soil $(\mathrm{PI}=16)$, non treated (above) and treated with $3 \%$ lime (below)

\subsection{Hydraulic performance}

Laboratory and full scale tests have shown that the permeability of a lime treated soil was identical to that of the same untreated soil provided it is compacted by kneading (for instance with a vibrating sheep foot roller) on the wet side of the Optimum Moisture Content (OMC).

Lime treatment also increases the resistance to internal erosion (Figure 1).

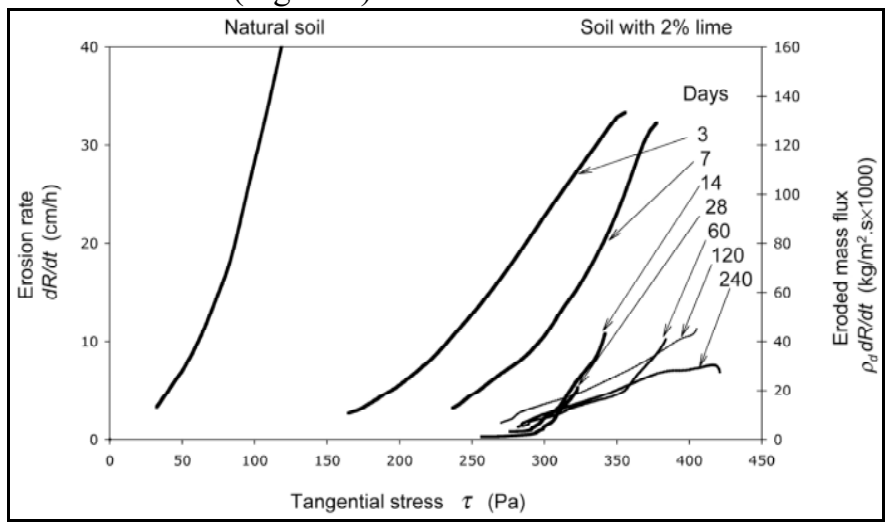

Figure 1. Hole Erosion Test (HET) curves of a clayey silt from Rhône River ( $\mathrm{PI}=11)$, untreated and treated with $2 \%$ lime, after several curing times [14]

For such a soil, the resistance to internal erosion (critical shear stress) is multiplied by more than 10 after 2 weeks thanks to the treatment with $2 \%$ of quicklime.

\subsection{Hydraulic performance}

To optimize the use of the soil lime component and therefore the design of the works, it was conducted an analysis of the requirements related to the lime treated material according to the functions attributed to the component in the hydraulic structure. Table 3 summarizes the results and should be read as follows: a given project may assign one or several functions to the soil lime component. The requirements are described below as well as the parameter(s) to be studied and the treatment process recommended. For instance, if the natural soil is too wet, one may only look for workability and determine the right dosage of lime to reach the necessary bearing capacity and density after compaction. 


\begin{tabular}{|c|c|c|c|c|c|c|}
\hline $\begin{array}{c}\text { Function } \\
\text { assigned to soil } \\
\text { lime } \\
\text { component }\end{array}$ & Workability & Stability & $\begin{array}{l}\text { Ability to retain } \\
\text { water }\end{array}$ & $\begin{array}{c}\text { Resistance to } \\
\text { internal erosion }\end{array}$ & $\begin{array}{c}\text { Surface } \\
\text { protection* }\end{array}$ & Evacuation* \\
\hline Requirements & $\begin{array}{l}\text { Improvement } \\
\text { of the use of } \\
\text { natural soils }\end{array}$ & $\begin{array}{c}\text { Stability } \\
\text { under own } \\
\text { weight }\end{array}$ & $\begin{array}{c}\text { Low } \\
\text { permeability }\end{array}$ & $\begin{array}{l}\text { Resistance to } \\
\text { internal erosion }\end{array}$ & $\begin{array}{c}\text { Resistance to } \\
\text { external } \\
\text { erosion }\end{array}$ & $\begin{array}{c}\text { Resistance to } \\
\text { high speed } \\
\text { flow }\end{array}$ \\
\hline $\begin{array}{l}\text { Parameters to } \\
\text { be studied }\end{array}$ & $\begin{array}{c}\text { Bearing } \\
\text { capacity } \\
\text { Density after } \\
\text { compaction }\end{array}$ & $\begin{array}{c}\text { Shear } \\
\text { strength } \\
\text { Tensile } \\
\text { strength } \\
\text { Compressive } \\
\text { strength }\end{array}$ & $\begin{array}{l}\text { Homogeneity } \\
\text { Permeability }\end{array}$ & $\begin{array}{l}\text { Homogeneity } \\
\text { Resistance to } \\
\text { hole erosion }\end{array}$ & $\begin{array}{c}\text { Homogeneity } \\
\text { Resistance to } \\
\text { surface } \\
\text { erosion }\end{array}$ & $\begin{array}{c}\text { Homogeneity } \\
\text { Resistance to } \\
\text { surface } \\
\text { erosion for } \\
\text { spillway }\end{array}$ \\
\hline $\begin{array}{c}\text { Recommended } \\
\text { treatment } \\
\text { process }\end{array}$ & $\begin{array}{c}\text { In place or } \\
\text { in central } \\
\text { plant }\end{array}$ & $\begin{array}{c}\text { In place or } \\
\text { in central } \\
\text { plant }\end{array}$ & $\begin{array}{c}\text { In place with } \\
\text { homogenisation } \\
\text { or in central } \\
\text { plant }\end{array}$ & $\begin{array}{c}\text { In place with } \\
\text { homogenisation } \\
\text { or in central } \\
\text { plant }\end{array}$ & $\begin{array}{c}\text { In central } \\
\text { plant }\end{array}$ & $\begin{array}{c}\text { In central } \\
\text { plant }\end{array}$ \\
\hline
\end{tabular}

Table 3. Functions and requirements regarding soil lime component

If workability and resistance to erosion are required, the performance to reach will be bearing capacity, density, homogeneity and resistance to internal erosion. The content and procedures of the studies shall be established in order to quantify these parameters.

In the field, the treatment can be done either in place or in a central plant. The first method is the most common. The modern equipment (spreaders and mixers) is able to produce high quality mixtures. The central plants are in a development phase. Recent models allow a better control of the lime dosage, the water content and the homogeneity of the mixtures.

\section{Experimental dike}

\subsection{Objectives}

Table 3 above shows that some parameters of lime treated soils are common and may be quantified by laboratory tests or in the field. Feedback from numerous projects is also consistent for some parameters.

From Table 3 again, it should be mentioned that resistance to surface erosion has not been qualified nor quantified yet. However surface erosion resistance could be of high interest, especially for low dams or dike if the designer could consider overflow over the earthfill itself, sparing expensive concrete or grouted rip rap spillways.

Surface erosion resistance cannot be properly analysed in lab test. Scale effect is too high to elaborate relevant and reliable laboratory test. It should be noted as well that lime treated soil should not be tested like other erosion protection devices such as mattresses, geogrid,... The latter are superficial and anchored in the earthfill, while lime treated soil makes the earthfill itself.

Therefore an experimental dike has been built within the French R\&D program DigueELITE about lime treated soils in hydraulic works. This dike will be tested against external erosion by applying steady artificial overflow. The experimental device itself is innovative and being developed within the DigueELITE program.

This experiment is also the opportunity to validate the construction methodology of lime treated earthfill for hydraulic works, which differs from usual methodology applied in soil treatment for other infrastructure. Methodology applied is described below.

The experimental dike will furthermore enrich the lime treated soil characteristic database with visual follow-up, permeability and internal erosion tests,...

The experimental dike is integrated in the rehabilitation works of the dike network along the river Vidourle. The contracting authority is EPTB Vidourle.

\subsection{Experimental dike design}

The experimental dike design has been set up with the following objectives:

- The dike should receive all the required tests and monitoring devices;

- The dike should be well integrated in its environment of real operational dikes;

- As experimental dike, it should not create any risk in case of failure or undesired behaviour, in the short and long term.

The dike has a typical dike cross section as shown in Figure 2. This cross section is taken in Zone II (lime treated soil). It should be noted that the dike is set within the Vidourle floodplain, along a meander. The dike has therefore no protection function. Furthermore, in case of flood event, water will raise both side of the dike.

Upstream and Downstream slopes are quite steep but corresponding to operational dikes around (1.5H/1V). Crest is $4 \mathrm{~m}$ wide at level $+11 \mathrm{mNGF}$ while natural ground in floodplain is about $+8.5 \mathrm{mNGF}$. 


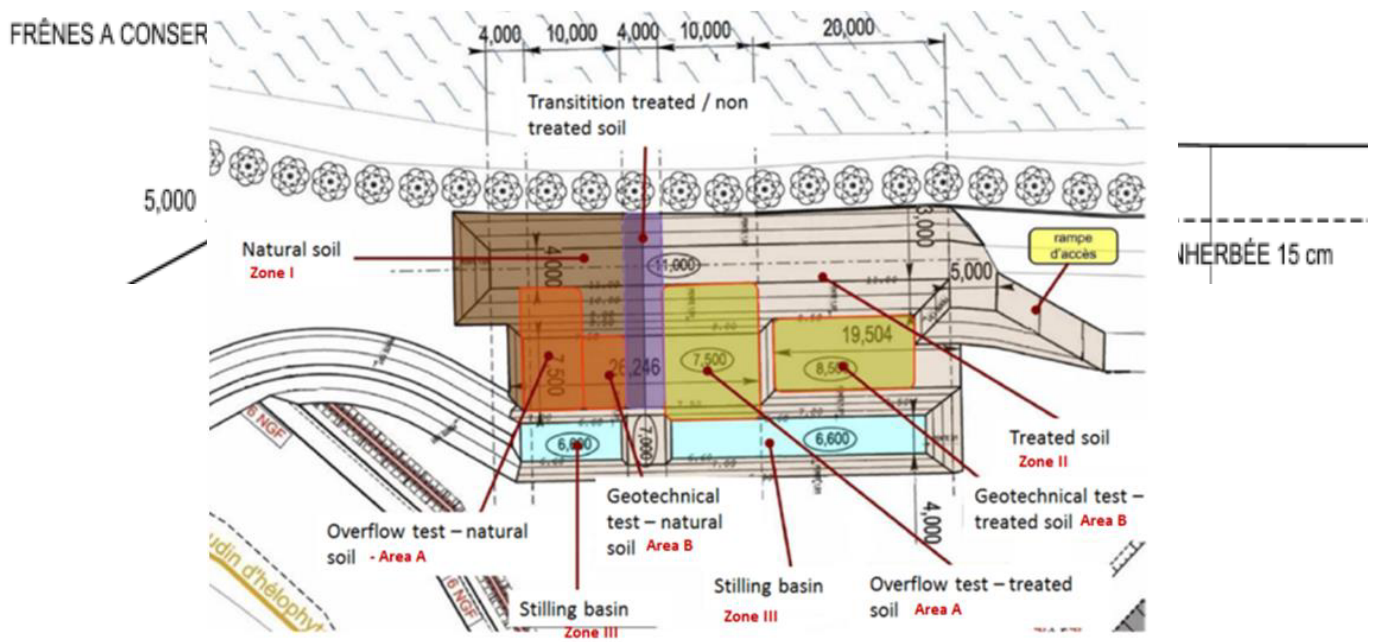

Figure 2. Experimental dike cross section (above) and lay out (below)

No filter and drain is considered, as for operational dikes. Unlike operational dikes however, no wire netting against burrowing animals is provided, in order to qualify lime treated soils resistance against those animals well present in the area.

The lay-out is presented in Figure 2 with different test zones:

- Zone I is made of natural, non treated soil as reference

- $\quad$ Zone II is made of lime treated soil

- Areas A (in Zone I and II) are dedicated to overflow test

- Areas B (in Zone I and II) are dedicated to other geotechnical tests

- Zone III is the stilling basin for the overflow test

\subsection{Experimental dike building description}

\subsubsection{Materials and preliminary lime treatment study}

The project has foreseen the reuse of excavated soil from the flood control area. This is a silty soil with a low plasticity index, which was treated by lime for the construction of the main part of the dike. The main characteristics of the soil are reported in Table 4.

\begin{tabular}{|c|c|c|c|}
\hline $\begin{array}{c}\text { Clay fraction } \\
(<\mathbf{2} \boldsymbol{\mu m}) \mathbf{( \% )}\end{array}$ & $\begin{array}{c}\text { Passing } \\
\text { through } \mathbf{8 0} \boldsymbol{\mu m} \\
\text { sieve } \mathbf{( \% )}\end{array}$ & $\begin{array}{c}\text { Methylene } \\
\text { Blue Value } \\
(\mathbf{g} / \mathbf{1 0 0} \mathbf{g})\end{array}$ & $\begin{array}{c}\text { Plasticity index } \\
\mathbf{( \% )}\end{array}$ \\
\hline 23 & 82 & 3.0 & 5 \\
\hline
\end{tabular}

\begin{tabular}{|c|c|c|}
\hline $\begin{array}{c}\text { Plastic limit } \\
\text { (\%) }\end{array}$ & $\begin{array}{c}\text { Liquid limit } \\
\text { (\%) }\end{array}$ & $\begin{array}{c}\text { Moisture } \\
\text { content at } \\
\text { sampling (\%) }\end{array}$ \\
\hline 23 & 28 & 14 to 17 \\
\hline
\end{tabular}

Table 4. Identification characteristics of excavated and stockpiled soil.
The lime used for the soil treatment lab tests is a CL 90-Q quick lime according EN 459-1 standard, containing $92 \%$ of available $\mathrm{CaO}$ and a reactivity (t60) of 2 minutes. The lime fixation point of the soil, determined according the Eades and Grim test (ASTM D6276-99a), is $1.5 \%$. A lightly higher dosage of $2 \%$ was selected to ensure the development of middle to longterm mechanical resistance. Same lime was used during the jobsite operations.

The changes induced by the lime treatment on the compaction behaviour of the soil are the following : the optimal moisture content (according Standard Proctor compaction) of untreated soil is $\rho \mathrm{d}=18.1 \mathrm{kN} / \mathrm{m}^{3}$ at ${ }_{\mathrm{wOMC}}=17.0 \%$. It is known that lime treatment leads to a displacement of the wOMC towards higher moisture contents and a reduction of the maximal dry density after compaction : the compaction characteristics of the silty soil treated with $2 \%$ quicklime are $\rho d=17.3 \mathrm{kN} / \mathrm{m}^{3}$ at wOMC $=18.7 \%$.

\subsubsection{Mixing and compaction condition, operations \& equipments}

After lime and soil mixing, the final materials must be humid, e.g. wet side of optimum conditions, in order to ensure the lowest permeability level (see 2.2 ). That means that up to $9 \%$ water had to be added because of very dry weather and low initial moisture content. The compaction must be performed with kneading operations (sheepfoot roller) to reach a density level $\geq 95 \%$ of the maximal dry density $\left(17.3 \mathrm{kN} / \mathrm{m}^{3}\right)$. The equipment used for lime treatment was a mobile soil mixing plant with a maximum production capacity of around 150 tons of treated soil per hour. It can precisely control the lime dosage through a continuous weighing of soil passing through the band, and offers a regular addition of water directly in the mixing bell (Figure 3, above). The compaction equipment is a VP5 sheepfoot roller, according the French Standard NF P 98-736 (Figure 3, below). 


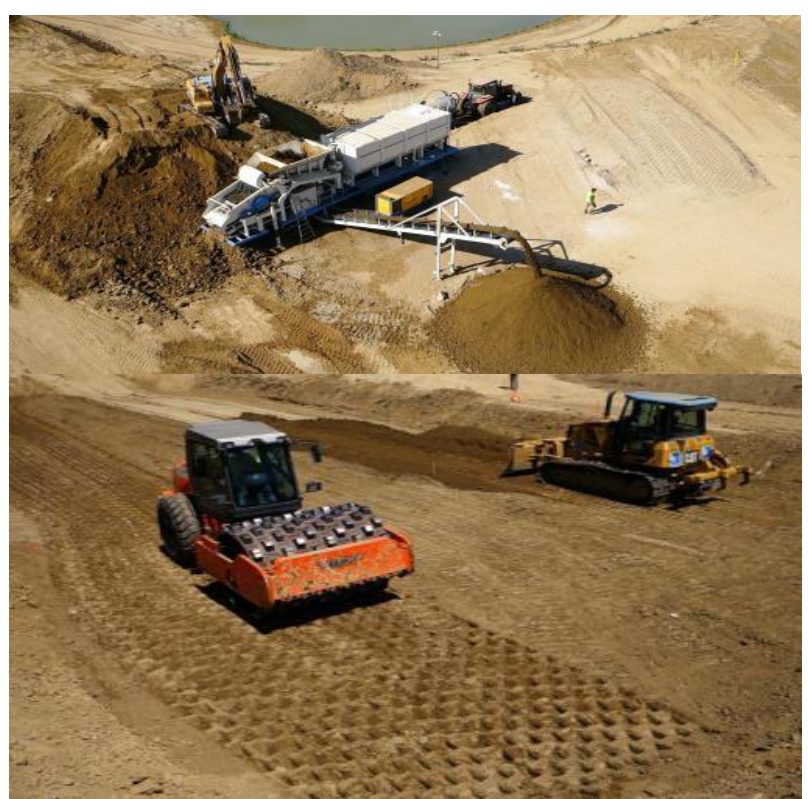

Figure 3. Mobile lime treatment plant (above); placement of treated soil and compaction by sheepfoot roller (below).

\subsubsection{Control during construction}

Controls during construction were focused on lime addition, water content of materials after placement, layers thickness and materials density after compaction (this last measurement by gamma densimeter). The measured lime and water contents and the calculated standard deviations of the mixture composition showed the high level of homogeneity of the treated soil, and therefore the consistency of the production using the mobile plant. The average layer thickness was $30 \mathrm{~cm}$ after compaction, the objectives in terms of water content $>$ OMC and density level were reached (Table 5).

Note that the average water content of the nontreated soil (Zone I) was determined around $15.7 \%$, close to its $\mathrm{OMC}$.

\begin{tabular}{|c|c|c|}
\hline & Water content (\%) & Lime dosage (\%) \\
\hline objective & $\begin{array}{c}\text { above OMC (19.6 to } \\
21.5 \%)\end{array}$ & 2.0 \\
\hline average & $\begin{array}{c}19.8(\mathrm{w}-\mathrm{wOMC}= \\
1.1 \%)\end{array}$ & 1.9 to 2.2 \\
\hline standard deviation & $\begin{array}{c}1.3(104 \\
\text { measurements) }\end{array}$ & - \\
\hline
\end{tabular}

\begin{tabular}{|c|c|}
\hline & Density level (\% $\mathbf{\rho d}$ at OMC) \\
\hline objective & equal or above $95 \%$ \\
\hline average & 95.2 \\
\hline standard deviation & $2.2 \quad \begin{array}{c}\text { (48 measurements, on a preliminary } \\
\text { test slab) }\end{array}$ \\
\hline
\end{tabular}

Table 5. Measurements performed on the lime-treated materials and layers after placement

\subsection{Dike performance}

Construction has been completed by August 2015 . So far only visual monitoring has been done and main interest of the inspections is comparison between zone I (natural ground) and zone II (lime treated soil) that leads us to some qualitative conclusions. Indeed, close and regular visual monitoring in the first few months after completion shows that soil treatment with lime enhances surface erosion resistance and seems to make soil hard enough to avoid or limit development of burrowing animals holes, as detailed hereunder.

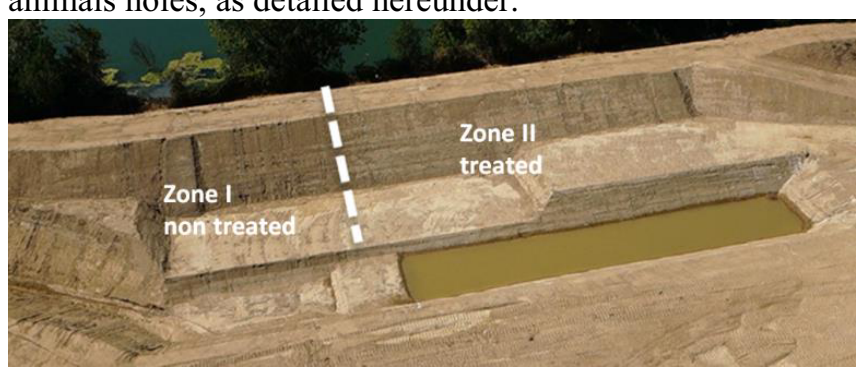

Figure 4. The dike before testing: non treated on the left side, lime treated on the right side

\subsubsection{External erosion resistance}

Usually, right after construction, earthfills may be damaged by rainfall and must be reworked before placing erosion protection devices (from grass to rip rap or stone mattresses).
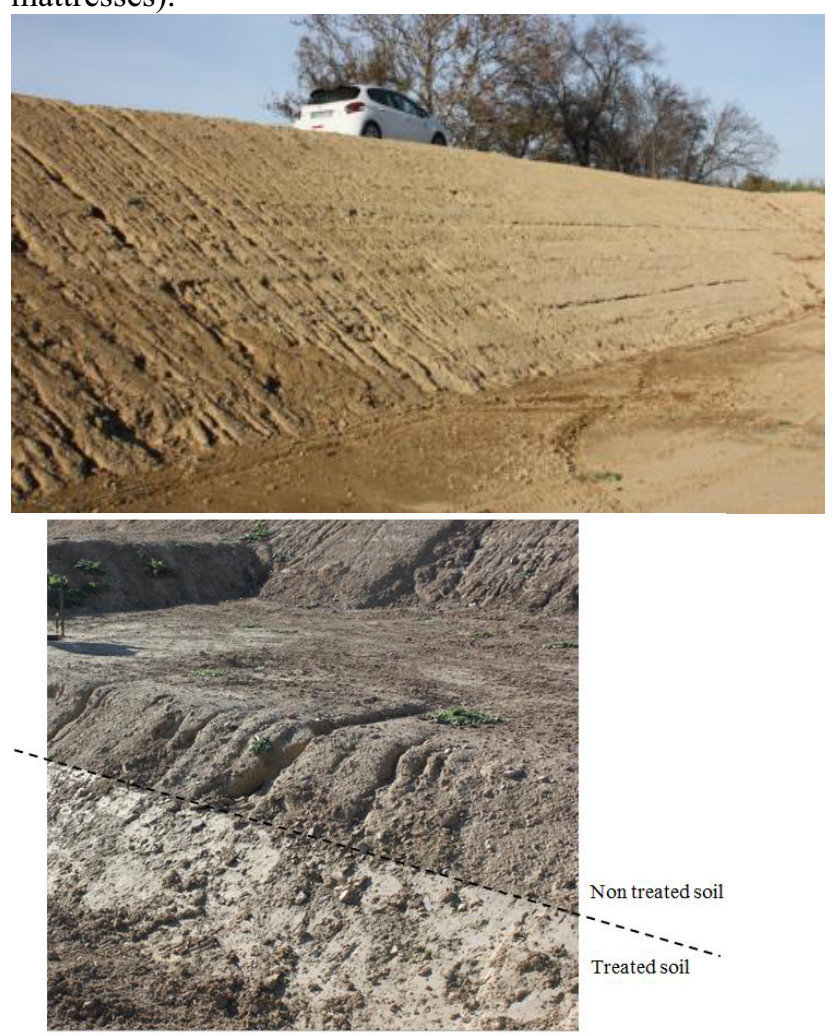

Figure 5. ABOVE : Non treated soil (Zone I) at left hand side, with erosion channels; lime treated soil (Zone II) at right hand side, with no erosion channel.

BELOW : Contrast of external erosion resistance between non treated soil (upper part) and lime treated soil (lower part) 
On the contrary, lime treated zone of the experimental dike does not show similar damages, giving preliminary assessment of erosion resistance of lime treated soil. Actually the treated earthfill does not change under rainfall, compared to non treated earthfill which shows several erosion channels. The latter are progressing by regressive erosion. Erosion channels may be dozens of $\mathrm{cm}$ deep at the crest level. In the lime treated zone, the slope appears smooth, without erosion track at the crest, as shown in Figure 5, above.

Contrast of erosion resistance is clearly shown in the stilling basin (Figure 5, below), constructed partly with lime treated soil (lower layers) and with non treated soil (upper layers). Erosion channels fades and then stops when reaching lime treated soil.

\subsubsection{Burrowing animals}

Burrowing animals holes have been observed in non treated soil (zone I) : 15 holes have been observed 4 months after completion, with depth varying from 10 to $70 \mathrm{~cm}$. However, no hole has been reported in lime treated soil (Zone II). Moreover, some attempts have been noticed, with claw signs or limited digging of the superficial parts, but with no success (Figure 6).

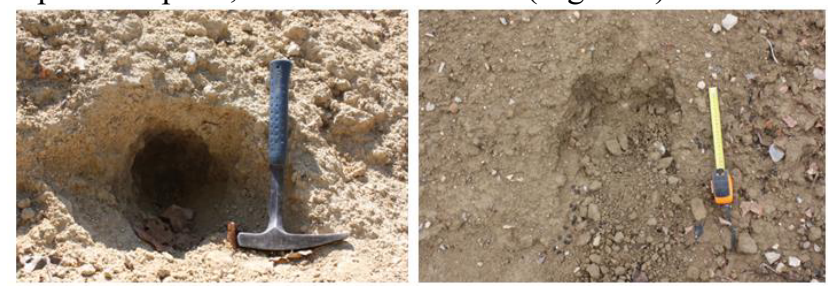

Figure 6. Burrowing animals holes in non treated soil (left) and unsuccessfull attempts in lime treated soil (right)

\subsection{Monitoring}

Monitoring program's objectives are the following:

- Quantify lime treated soil resistance to external erosion and compare with non treated soil

- Assess dike durability

- Confirm previous results about lime treated soil in hydraulic works, especially regarding permeability.

\subsubsection{Surface erosion field test}

Main objective regarding lime treated soil performance is to quantify resistance to surface erosion. Therefore a specific device has been developed in the frame of the R\&D Program by the research institute IRSTEA, partner of project. Along designing the device itself, IRSTEA is currently developing the test protocol and the theoretical background for result interpretation.

This device aims to create a steady flow along the embankment slope in a channel, about $60 \mathrm{~cm}$ wide. A schematic view of the principle of the overflow test is given in Figure 7.
Flow is increased gradually, increasing nappe depth at the top and flow velocity at the toe. The flow is stopped according to a previously defined protocol in order to observe the embankment, looking for possible erosion. The channel is laser-scanned in order to quantify the erosion thanks to post-processing methods specifically developed for this purpose.

The test is conducted in the Zone I (non treated soil) and Zone II (lime treated soil), in order to compare performance.

Results are processed with final objective, within the project, to give a flow velocity up to which no erosion is observed. Once erosion is initiated, erosion rate is the second result expected.

Field tests should be carried out first semester of 2016; results should be available before end 2016 .

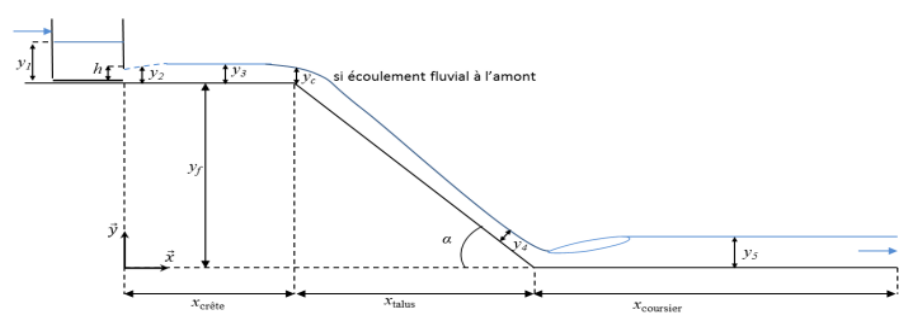

Figure 7. Surface erosion field test

It should be noted that this device is designed to be used on various dike configurations, not only on dike with lime treated soil.

\subsubsection{Earthfill behaviour}

Following sensors are integrated within the earthfill, in Zone I (non treated soil) as well as in Zone II (lime treated soil) : water content and temperature sensors and suction sensor. Finally, a ground monitoring well is set in the dike. Those sensors will allow a close monitoring of the exchanges between the dike and its environment, their evolution during the dike lifetime, and the comparison between non treated and lime treated soil.

In addition to this, geotechnical tests will be conducted at different time periods after construction in order to analyse the evolution of mechanical characteristics, such as bearing capacity, cohesion and compressive strength, permeability and resistance to internal erosion. Support should be given by a $\mathrm{PhD}$ work related to lime treated soil durability, to be started in the near future.

\subsubsection{Dike durability}

Dike durability will be monitored through monthly or bi-monthly site visits with detailed visit reports. Any evolution in the dike will be tracked, and should be investigated in order to understand the physical process behind apparent modifications. 
Interesting information will be given by evolution of the stilling basin, that is under water, with (little) water level fluctuation.

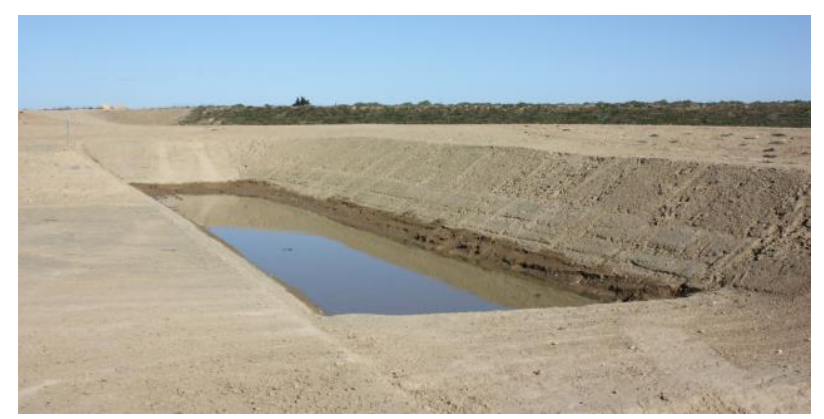

Figure 8 : Stilling basin in February, 2016

\section{Dike design perspective}

\subsection{General}

Common use of lime treatment is soil stabilisation. This is applicable to earthen hydraulic structures as well but generally with no or little effect on the design (layout, cross sections, appurtenances,...) of hydraulic work project. However design may be significantly modified and optimised when taking into consideration lime treated soil performance like enhanced stability, internal and external erosion resistance and low permeability.

Possible design optimisations are discussed below for earthfill dikes.

Optimisations for dikes and low dams design are related to the performance described in table 3 .

- Stability: improved mechanical stability (see table 1 and 2) may lead to slope structure modification. Slope steepening may be considered to address challenges such as limited material availability, limited space available,... Knowledge and feedback is sufficient today to consider improved mechanical stability while designing a project.

- Low permeability: as lime treated soil may keep same permeability level as non treated soil, no extra watertightening system is required. Attention should be paid while defining construction methods.

- Internal erosion resistance: internal erosion resistance of lime treated soil allows simplification of filters and drains system. Filters and drains within the earthfill may even not be required anymore, if internal erosion resistance is confirmed by preliminary laboratory tests. However it remains mandatory to study internal erosion protection device at the earthfill/foundation interface. Limited filters and drains device may simplify the cross section for construction and reduce the need for materials not always available at site in silty environment (clean sand). Theoretical knowledge is wide on the subject, while feedback is currently being built. A project may be designed today considering internal erosion resistance of lime treated soil, provided care is taken in material characterisation and risk assessment.

- Surface protection: depending on hydraulic conditions, erosion protection may be drastically reduced. As the lime treated earthfill is erosion resistant, surface protection such as rip-rap, gabions,... may not be required anymore. Benefits are high with respect to cost and environment. This is mostly applicable for upstream side where hydraulic stress is flow in case of dike. Theoretical knowledge and feedback are rather limited but being built today, namely with DigueELITE project mentioned above.

- Evacuation: sufficient resistance against high flow velocities may be the major benefit of lime treated soil. Assuming resistance to velocities up to 5 to $7 \mathrm{~m} / \mathrm{s}$, the earthfill itself may play the role of spillway and the design of dike and low dams may be drastically changed, as detailed below. As well as for surface protection, theoretical knowledge and feedback are rather limited but being built today, namely with DigueELITE project.

\subsection{Focus on dike spillways}

Spillways for dikes are less commonly planned by the Engineers and the Authorities, compared to spillways for dams. In that perspective, design criteria for a dike spillway are less commonly accepted than for a dam. Anyway, considering dike overflow while in the design process becomes more and more common, and it should intensify in the future.

If overflow tests are successful and show that lime treated soil is resistant to sufficient flow velocities (order of magnitude 5 to $7 \mathrm{~m} / \mathrm{s}$ ), steady overtopping in case of flood could be planned to occur on the earthfill itself. In that case, no more "hard" spillway (concrete, grouted rip rap, gabions,...) may be required, saving cost and preserving landscape and environment.

Furthermore, steady overtopping can be organised over long dike sections. This would lower the specific flow per meter of crest, consequently decreasing the nappe depth at the entrance of the spillway and hence the required freeboard.

Decreasing required freeboard may lead to lower the crest level and hence reduce the cost for same safety level. Or, for same crest level, safety level could be increased. This may be another strong benefit of lime treated soil.

This shows that if surface erosion resistance of lime treated soil is confirmed, it opens new possibilities for designing cost effective and safe dikes.

In this case, for a same crest level, protection level given by the dike would be higher as risk of breach due to overflow will be limited.

\section{Conclusion}

Lime treated soils are not commonly used in hydraulic works, and in any case barely used to take advantage of the whole range of their properties.

As for now, on top of reuse of poor soil available at site, a designer could consider performance such as mechanical stability, low permeability and resistance to internal erosion, to optimise a dike project and decrease construction costs. Data and feedback are sufficient today. 
In the near future, it is expected that the experimental dike along river Vidourle will confirm assumptions related to resistance to surface erosion, based on previous research program. If confirmed and quantified by the experimental dike, and later by other experiments, surface erosion resistance may greatly impact the design of dikes: steady overflow could be organised on the earthfill itself and the need for concrete or other "hard" spillways may be drastically reduced.

In this perspective, the experimental dike and the associated in-situ overflow test are of great interest and should deliver first results in the first semester 2016.

\section{Acknowledgements}

Authors gratefully acknowledge all the members of the consortium "DigueELITE" as well as EPTB Vidourle for their support and contributions. Authors also gratefully acknowledge M T. OZTURK for his intensive laboratory work during the dike construction, as well as the Contractor, Berthouly TP.

\section{References}

1. Perry J.P. (1977) Lime treatment of dams constructed with dispersive clay soil, Transactions of the ASAE, vol. 20, 99, 1093-1099.

2. ANCOLD (1978) Bulletin of the Australian National Committee On Large Dams, p. 51.

3. Gutschick K.A. (1978) Lime stabilization under hydraulic conditions, $4^{\text {th }}$ lime congress, Hershey (PA), pp $1-20$.

4. Gutschick K.A. (1985) Canal lining stabilization proves successful. Pit \& Quarry, pp.58-60.

5. Knodel P.C. (1987) Lime in canal and dam stabilization, US Bureau of Reclamation, Report No GR87-10, 21p.

6. Fleming R.L., Sills G.L. \& Stewart E.S. (1992) Lime stabilization of levee slope, $2^{\text {nd }}$ Interagency Symposium on Stabilization of soils and other Materials, Metairie, Louisiana, pp 79-87.

7. USBR, U.S. Bureau of Reclamation (1998) Earth Manual, Denver CO, 349p.

8. Stapledon D, MacGregor P, Bell G \& Fell R. (2005) Geotechnical Engineering of Dams, Transactions of the $A S A E$, vol. 20, 99, 1093-1099

9. US Army Corps of Engineers (2010) Revised Final Independent External Peer Review Report Alton to Gale Organized Levee Districts, Illinois and Missouri, Letter Report, http://www.usace.army.mil/Portals/2/docs/civilworks/Pro ject\%20Planning/alton2gale.pdf

10. Chevalier C, Haghighi I \& Herrier G (2012)

Resistance to erosion of lime treated soils: a complete parametric study in laboratory, Proceedings of the 6th
International Conference on Scour and Erosion, Paris, France, pp 161-168.

11. Herrier G. \& Bonelli S. (2014) Internal erosion resistance of soils treated with lime: An evolutive benefit, Proceedings of the 7th International Conference on Scour and Erosion, Perth, Australia.

12. Makki-Szymkiewicz L, Fleureau J.M., Hibouche A, Taibi S, Herrier G, Lesueur D (2015) Evolution of the properties of lime-treated silty soil in a small experimental embankment, Engineering Geology, 191, pp 8-22.

13. Little D.L. (1995) Handbook for Stabilization of Pavement Subgrades and Base Courses with Lime, Dubuque (Iowa), Published by Kendall/Hunt Publishing Company.

14. Bonelli S. (2013), Erosion in Geomechanics Applied to Dams and Levees, Wiley/ISTE, 388 p. 